Volume 5 Nomor 2 Ed. Desember 2019 : page 124-138 p-ISSN: 2460-805X e-ISSN : 2550-0295

DOI : 10.24252/iqtisaduna.v5i2.10550

\title{
Perspektif Islam Terhadap Distribusi Kekayaan Dalam Hubungan Juragan-Punggawa Sawi Pada Kehidupan Nelayan
}

\author{
Ardhina Nur Aflaha \\ STAI Al-Azhar Gowa \\ Jln. Tamangapa Raya III No. 16, Antang, Kota Makassar \\ E-mail: ardhinaaflaha@gmail.com
}

Diterima: 27 September 2019； Direvisi: 12 Desember 2019; Diterbitkan: 17 Desember 2019

\begin{abstract}
Abstrak,
Tujuan penelitian ini secara umum adalah untuk mengetahui bentuk keadilan distribusi kekayaan dalam hubungan juragan-punggawa sawi dalam kehidupan nelayan di Desa Sampulungan. Dan tujuan khusus dari penelitian ini yakni, untuk mengetahui bentuk distribusi kekayaan dalam hubungan juragan-punggawa sawi dalam kehidupan nelayan di Desa Sampulungan perspektif keadilan ekonomi Islam. Penelitian ini merupakan penelitian deskriptif kualitatif. Penelitian ini di lakukan di Desa Sampulungan Kecamatan Galesong Utara Kabupaten Takalar. Pendekatan yang digunakan adalah pendekatan teologis normatif, sosiologi dan pendekatan ekonomi Islam. Metode pengumpulan data meliputi wawancara, observasi dan dokumentasi. Data yang terkumpul dianalisis melalui beberapa tahapan yakni reduksi data, penyajian data dan tahap penarikan kesimpulan. Populasi dari penelitian ini meliputi juragan, punggawa dan sawi dari Desa Sampulungan Kecamatan Galesong Utara Kabupaten Takalar dengan menggunakan metode snowball sampling.Hasil penelitian ini menunjukkan bahwa bentuk distribusi kekayaan juragan-punggawa sawi di Desa Sampulungan tidak melanggar distribusi kekayaan perspektif ekonomi Islam. Pada prakteknya distribusi kekayaan yang merata melalu kerja sama dalam bentuk kemitraan atau syirkah 'ainan.
\end{abstract}

Kata Kunci: Sampulungan, Syirkah, Distribusi Kekayaan, Juragan, Punggawa

\section{Abstract,}

The purpose of this study in general is to determine the fairness of the distribution of wealth in the relationship of mustard servants in the lives of fishermen in the village of Sampulungan. And the specific purpose of this research is to find out the form of wealth distribution in the relationship of mustard-servant servants in the life of fishermen in the village of Sampulungan in the perspective of Islamic economic justice. This research is a qualitative descriptive study. This research was conducted in the Village of Sampulungan, Galesong Utara District, Takalar Regency. The approach used is a normative theological approach, sociology and Islamic economic approach. Data collection methods include interviews, observation and documentation. The data collected was analyzed through several stages namely data reduction, data presentation and conclusion drawing stages. The population of this study includes skipper, retainer and mustard from the Village of Sampulungan, North Galesong District, Takalar Regency by using snowball sampling method. The results of this study indicate that the form of wealth distribution of mustardretainer in Sampulungan Village does not violate the wealth distribution perspective of Islamic economics. In practice the equitable distribution of wealth through cooperation in the form of partnerships or syirkah inan ainan.

Keywords: Sampulungan, Syirkah, Wealth Distribution, Skipper, Courtier 


\section{Perspektif Islam Terhadap Distribusi Kekayaan Dalam Hubungan \\ Juragan-Punggawa Sawi Pada Kehidupan Nelayan \\ Ardhina Nur Aflaha \\ DOI: 10.24252/iqtisaduna.v5i2.10550}

\section{PENDAHULUAN}

Dalam perspektif Islam, bahwasanya kebijakan ekonomi berarti suatu sistem pengaturan yang sanggup mengembangkan kehidupan ekonomi masyarakat yang wajar dan adil. Ekonomi Islam sendiri haruslah berlandaskan pada al-Qurān, hadit dan ijma' ulama. Nilai-nilai ekonomi Islam ini merupakan bagian integral dari keseluruhan ajaran Islam yang komprehensif dan telah dinyatakan sebagai ajaran yang sempurna.

Ekonomi Islam memiliki kebijakan dalam distribusi pemasukan, baik antara unsurunsur produksi maupun antara individu masyarakat dan kelompoknya, di samping pengembalian distribusi dalam sistem jaminan sosial yang diatur dalam ajaran Islam. Islam menggariskan bahwa dalam harta pribadi terdapat hak-hak orang lain yang harus ditunaikan dan ini tidak dikenal dalam bentuk ekonomi konvensional (Idri, 2015).

Indonesia merupakan Negara kepulauan, di mana 60\% dari penduduk Indonesia hidup di wilayah pesisir. Sebagian besar diantaranya menggantungkan hidup kepada keberadaan sumberdaya alam pesisir dan lautan. Sehingga tidaklah mengherankan jika sebagian besar kegiatan dan aktifitas sehari-harinya selalu berkaitan dengan keberadaan sumberdaya sekitarnya. Indonesia sangat kaya akan kekayaan laut seperti hutan mangrove, terumbu karang, pada lamun, rumput laut serta perikanan (Razali, 2004). Tetapi dari kenyataannya tetap saja masyarakat pesisir termasuk golongan masyarakat miskin terbesar di Indonesia.

Masyarakat daerah pesisir merupakan masyarakat yang mayoritas penghasilannya sehari-hari dari laut, mereka itu adalah para nelayan. Masyarakat pesisir juga dapat diartikan sekelompok warga yang tinggal di wilayah pesisir yang hidup bersama dan memenuhi kebutuhan hidupnya dari sumber daya di wilayah pesisir. Masyarakat yang hidup di kota dan pemukiman pesisir memiliki karakteristik secara sosial ekonomis sangat terkait dengan sumber perekonomian dari wilayah laut.

Berdasarkan dari beberapa kasus dalam masyarakat pesisir di mana pemilik modal melakukan monopoli dalam hubungan kerja sama dalam bentuk bagi hasil yang dijalin antara juragan -punggawa sawi. Juragan adalah pemilik kapal dan pemodal awal dari kegiatan penangkapan ikan yang dilakukan di Desa Sampulungan. Punggawa adalah nahkoda kapal sedangkan sawi adalah nelayan biasa yang bertugas di atas kapal dalam proses penangkapan ikan ataupun penangkapan telur ikan.

Contohnya pada kasus bagi hasil antara punggawa dan sawi di kelurahan Barang Lompoa kota Makassar, di mana sistem bagi hasil yang diterapkan oleh Punggawa adalah 2;1, yaitu satu bagian pemilik alat tangkap, satu bagian untuk Punggawa dan satu bagian untuk Sawi, maka pihak punggawa mendapatkan 2 bagian yaitu satu bagian dari kepemilikan alat 


\section{Perspektif Islam Terhadap Distribusi Kekayaan Dalam Hubungan \\ Juragan-Punggawa Sawi Pada Kehidupan Nelayan Ardhina Nur Aflaha \\ DOI: 10.24252/iqtisaduna.v5i2.10550}

tangkap dan sawi memperoleh 1 bagian termasuk di dalamnya punggawa laut(nahkoda). Dimana jika dipresentasekan maka 66,67\% keuntungan di tujukan pada punggawa dan 33,33\% di berikan pada sawi yang di mana sawi tidak hanya terdiri dari 1 orang tetapi 9 sampai 10 orang. Hal ini menggambarkan adanya distribusi kekayaan yang tidak adil dalam hubungan bagi hasil antara punggawa-sawi di Kelurahan Barang Lompo kota Makassar.

Selain kasus diatas hal sama terjadi pada nelayan di Sape-Bima hasil tangkapan kakap merah yang berlaku di pasar Rp. 22. ooo/kg harus djual ke pemodal dengan harga Rp. 15 . ooo/kg. Hal ini disebabkan karena sebelumnya nelayan yang tidak memiliki uang untuk memenuhi kebutuhannya melakukan pinjaman kepada pemilik modal dan akhirnya pemilik modal memberikan pinjaman dengan syarat adanya ikatan kerja atau hasil tangkapan yang dijual kepada pemilik modal dengan harga lebih rendah (Satria, 2014).

Desa Sampulungan merupakan salah satu daerah pesisir di Kabupaten Takalar yang lebih tepatnya berlokasi di Kecamatan Galesong utara. Masyarakat Desa Sampulungan mayoritas memilki ikatan juragan-punggawa sawi. Juragan-punggawa sawi ini terdiri atas pemilik modal, nahkoda dan nelayan. Salah satu hubungan yang dibangun dalam segi ekonomi yakni bagi hasil di mana juragan untuk hasil tangkap mendapatkan 25\% dari laba bersih, sedangkan sisanya diberikan kepada punggawa sawi dengan pembagiannya 2:1. Untuk punggawa sawi sendiri terbagi atas 2 kategori yakni punggawa atau nakhoda dan sawi atau nelayan, 2 bagian untuk punggawa sedangkan 1 untuk nelayan di mana 1 ini tidak untuk 1 nelayan saja tetapi berlaku untuk seluruh nelayan yang ikut dalam penangkapan ikan.

Dalam kerja sama yang di anut juragan-punggawa sawi pihak juragan menginvestasikan jolloro sedangkan pihak punggawa sawi memberi modal berupa bahan yang akan digunakan selama melaut. Tidak hanya berupa materi tetapi juga makanan dan minuman yang akan di konsumsi maupun kapal yang digunakan dalam proses penangkapan ikan. Tetapi modal yang di bawa oleh punggawa-sawi merupakan pinjaman dari juragan. Hal ini berarti resiko yang akan ditanggung oleh juragan juga sangat besar dalam proses penangkapan ikan ini. Belum lagi jika proses penangkapan ikan ini tidak membuahkan hasil, maka punggawa-sawi akan membayar utang tersebut apabila memiliki uang ataupun setelah penangkapan selanjutnya.

Berdasarkan hal tersebut, peneliti tertarik untuk menganalisis distribusi kekayaan dalam hubungan juragan-punggawa sawi di Desa Sampulungan Kecamatan Galesong Utara Kabupaten Takalar. 


\section{Perspektif Islam Terhadap Distribusi Kekayaan Dalam Hubungan Juragan-Punggawa Sawi Pada Kehidupan Nelayan Ardhina Nur Aflaha \\ DOI: 10.24252/iqtisaduna.v5i2.10550}

\section{TINJAUAN TEORITIK}

Distribusi merupakan kajian penting dan menempati posisi strategis dalam ekonomi mikro baik dalam sistem ekonomi Islam maupun konvensional sebab pembahasan distribusi ini tidak hanya berkaitan dalam aspek ekonomi belaka tetapi juga aspek sosial dan politik sehingga menjadi perhatian pemikir ekonomi Islam dan Konvensional sampai saat ini (Sudarsono, 2004).

Distribusi kekayaan akan mempengaruhi kehidupan ekonomi suatu lingkungan. Dengan adanya distribusi yang adil dan merata maka peredaran kekayaan tidak akan berpihak pada suatu kelompok saja. Salah satu distribusi yang disinggung dalam fiqih ekonomi Umar bin Khattab adalah distribusi pemasukan. Yang dimaksudkan distribusi pemasukan di sini adalah apa yang dikenal dalam ekonomi dengan istilah pembagian berdasarkan tugas dan tanggung jawab, pendistribusian pemasukan antara unsur-unsur produksi yang andil dalam merealisasikannya (al-Haritsi, 2006).

Salah satu distribusi kekayaan yang dianjurkan adalah distribusi yang bersifat produktif, dimana yang mendisitribusikan memberikan modal untuk membuka lapangan kerja. Salah satunya adalah dengan melakukan syirkah. Syirkah merupakan bentuk kerja sama dua atau lebih untuk melakukan sebuah perniagaan atau usaha yang motifnya ialah untuk memperoleh keuntungan (Hanafia, 2004). Menurut istillah seperti yang dikemukakan Sayyid Saiq dalam kitbanya Fiqh al-Sunnah adalah persekutuan dalam urusan harta atau dua orang atau lebih bahwa mereka akan berniaga dengan keuntungan dibagi dua. Dalil diperbolehkannya syirkah berdasarkan hadit Nabi Salllahu alaihi Wa sallam:

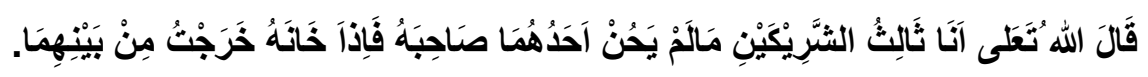

(رواه ابو دوود و الحاكم)

Artinya:

Allah berfirman dalam hadits qudsi: "Aku adalah pihak yang ketiga dari dua orang yang berserikat selama salah seorang diantaranya tidakmengkhianati temannya. Bila salah seorang diantara keduanya berkhianat, Aku keluar dari perselisihan keduanya"(HR. Abu Daud dan Hakim).

Terdapat pula dalam QS Shād ayat 24

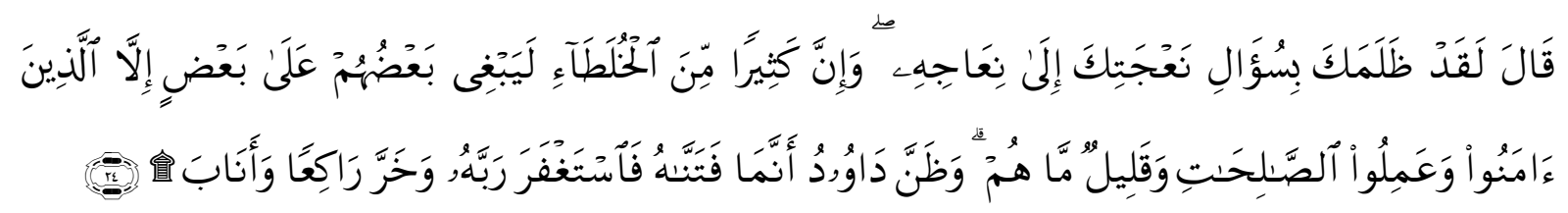




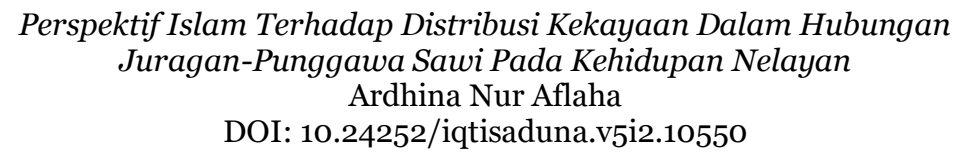

Terjemahnya:

Daud berkata: "Sesungguhnya Dia telah berbuat zalim kepadamu dengan meminta kambingmu itu untuk ditambahkan kepada kambingnya. dan Sesungguhnya kebanyakan dari orang-orang yang berserikat itu sebahagian mereka berbuat zalim kepada sebahagian yang lain, kecuali orang-orang yang beriman dan mengerjakan amal yang saleh; dan Amat sedikitlah mereka ini". dan Daud mengetahui bahwa Kami mengujinya; Maka ia meminta ampun kepada Tuhannya lalu menyungkur sujud dan bertaubat.

Dalam kitab tafsir al-Qasimì menjelaskan maksud dari ayat di atas ialah pencampuran harta dari 2 orang sahabat yang bermitra dan pentingnya kejujuran dalam suatu kerja sama dan tidak mendzalimi sahabat yang lain.

Salah satu bentuk dari syirkah adalah syirka 'ainan dalam syirkah tersebut masingmasing dari kedua pihak atau lebih mengeluarkan modal dan keterampilan dalam berusaha. Dalam pemberian modal tidak haruslah sama begitu juga dengan keterampilan dalam usaha tersebut. Syarat dari syirkah al-'inān yakni :

a) Syarat yang berkaitan dengan syarik :yaitu kedua pihak atau lebih mengatur jumlah modal yang akan berikan dan saling membagi pekerjaan sesuai dengan keahlian masing-masing dalam bidang usaha. Para syarik dalam syirkah 'ainan juga diperbolehkan membuat syarat-syarat yang berkaitan dengan bidang usaha yang boleh atau tidak boleh dilakukan oleh masing-masing pihak syarik.

b) Keuntungan yang diperoleh harus ditentukan berdasarkan jumlah modal yang disertakan (proporsional), tetapi pendapat Abu Hanifah mengatakan boleh membagi hasil tidak sesuai dengan modal yang di masukkan. Dalam kitab al-Mu’jam al- Wasit keuntungan dalam konteks ekonomi Islam adalah perbedaan antara harga modal dengan harga barang yang dijual.

c) Ulama Hanafiah dan Syafi'iyah berpendapat kerusakan harta yang dijadikan modal usaha dalam perkongsian menjadi sebab batalnya syirkah apabila kerusakan barangmodal tersebut terjadi sebelum disatukan (ikhtilath) (Hasanuddin, 2012).

\section{METODE PENELITIAN}

\section{Lokasi Penelitian}

Penelitian ini dilakukan pada juragan-punggawa sawi di Desa Sampulungan Kecamatan Galesong utara Kabupaten Takalar. 


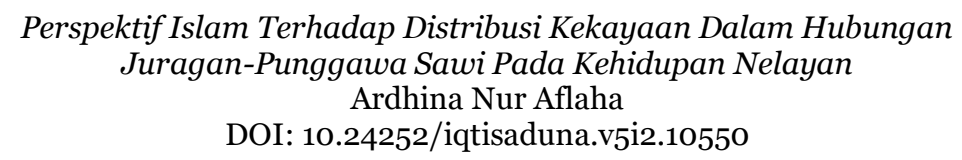

\section{Populasi dan Sampel}

Populasi dari penelitian ini meliputi juragan, punggawa dan sawi dari Desa Sampulungan Kecamatan Galesong Utara Kabupaten Takalar yang berjumlah 534 orang yang total penduduknya 2358 orang. Di mana populasi tersebut terbagi atas Sampulungan caddi 74 orang, Sampulungan lompo 327 orang, Sampulungan Beru 33 orang, dan Sampulungan 100 orang.

Sampel dari penelitian ini berjumlah 5 orang, teknik yang digunakan adalah snowball sampling. Di mana dalam penelitian ini dimulai dari satu orang sampel yakni Dg. Limpo, yang merupakan juragan dengan modal terbesar di Desa Sampulungan.

\section{Sumber Data}

Sumber data dalam penelitian ini menggunakan dua jenis sumber data yaitu: sumber data primer, bersumber dari pengamatan berupa informasi yang berasal dari juraganpunggawa sawi Desa Sampulungan Kecamatan Galesong Utara Kabupaten Takalar yang terikat dalam hubungan kerja sama . Sumber data sekunder adalah merupakan sumber data yang tidak langsung dari informan atau data tambahan yang digunakan yang berupa dokumenter yang bersumber dari buku-buku yang membahas distribusi kekayaan dalam perspektif Ekonomi Islam, hasil-hasil penelitian, jurnal, majalah, media cetak, dan dokumendokumen lainnya yang berkaitan dengan penelitian ini, serta beberapa pandangan ahli Ekonomi Islam. Dalam hal ini segala sumber informasi media di atas yang mendukung kerja peneliti (Azwar, 2004).

\section{Teknik Analisis Data}

Pendekatan yang digunakan adalah pendekatan teologis normatif, sosiologi dan pendekatan ekonomi Islam. Metode pengumpulan data meliputi wawancara, observasi dan dokumentasi. Data yang terkumpul dianalisis melalui beberapa tahapan yakni reduksi data, penyajian data dan tahap penarikan kesimpulan.

\section{HASIL DAN PEMBAHASAN}

\section{Distribusi Kekayaan dari Segi Bagi Hasil \\ Bentuk kerja sama}

Bentuk kerja sama yang terjalin dalam hubungan juragan-punggawa sawi di Desa Sampulungan adalah kemitraan. Hal tersebut dapat kita lihat dari hasil analisis yang terjadi pada kerja sama antara juragan-punggawa sawi. Juragan memberikan modal berupa kapal atau disebut jolloro sedangkan punggawa-sawi akan memberikan modal berupa bahan dan 


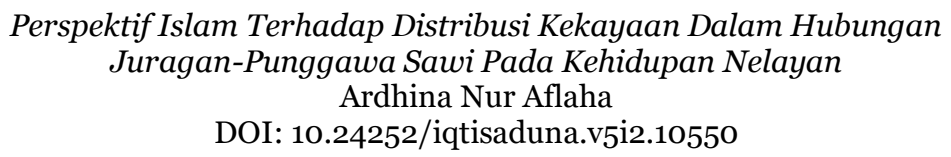

barang yang dibutuhkan selama melaut. Juragan dan punggawa-sawi pun punya tugas masing-masing, juragan bertugas sebagai penjual hasil tangkapan sedangkan punggawa-sawi bertugas melakukan penangkapan. Pembagian modal dan kerja dapat dilihat pada tabel berikut

Tabel 1. Model Kerja Sama Bagi Hasil

\begin{tabular}{lllll}
\hline & Kapal & Alat & Tenaga & Biaya \\
\hline Juragan & $\sqrt{ }$ & $\sqrt{ }$ & $\sqrt{ }$ & \\
\hline Punggawa-sawi & & & $\sqrt{ }$ & $\sqrt{ }$ \\
\hline
\end{tabular}

Sumber : Data primer yang telah di olah 2017

Juragan akan mengambil keuntungan sebesar 25\% dari keuntungan yang didapatkan dari kegiatan penangkapan. Sedangkan untuk punggawa-sawi akan dibagi sesuai dengan jumlah punggawa-sawi yang ikut serta dalam penangkapan di mana punggawa kapal akan mendapatkan jatah dua nelayan atau bisa disebut dengan pembagian 2:1. Hal tersebut berdasarkan wawancara dari Riswan”

Kami di sini kalau ikan sudah di jual kami ambil 25\%, terus 75\% di bagi ke nelayan. Nanti mereka bagi 2:1, Punggawa itu dapat dua jatahnya nelayan karena punggawa yang bawa kapal. Seperti Dg.Tompo dia dapat dua kali jatah nelayan. Semua di sini begitu sistemnya, juragan dapat $25 \%$ terus yang $75 \%$ yang dibagiseperti tadi. Tidak ada yang protes karena sudah lama perjanjiannya seperti ini.

Hal tersebut juga sejalan dengan wawancara yang dilakukan kepada Dg. Tompo

Iya, kami di sini stor ikan ke juragan dulu. Setelah di jual juragan nanti potong uang barang yang sudah kita ambil. Setelah itu juragan akan potong $25 \%$ untuk keuntungannya. Sisanya diberikan ke saya, saya bertugas untuk membagikan uang ke nelayan karena saya punya tanggung jawab sama mereka. Jadi kalau anggotaku dapat Rp. 500.00o saya dapat Rp 1.000.0oo. tapi kalau ditanya jumlah terbanyak yang pernah saya dapat itu sekitaran Rp. 2.0oo.ooo berarti anggota saya dapat Rp.1.00o.ooo.

Keuntungan tersebut akan di bagi berbeda apabila ikan hasil tangkapan di jual oleh perantara, karena untuk Desa Sampulungan sendiri terkadang juragan tidak menjual hasil tangkapan secara langsung tetapi melalui perantara maka perantara tersebut akan mendapatkan keuntungan $5 \%$ dari hasil penjualan sedangkan jatah untuk juragan dan punggawa-sawi tetap. Hal tersebut dipengaruhi oleh musim dari ikan itu sendiri, nilai tinggi mempengaruhi tempat punggawa-sawi akan menyandarkan kapalnya. Untuk desa Sampulungan, punggawa-sawi memiliki 2 pilihan yakni menjualnya di Beba Takalar ataupun di Paotere di Makassar. Terkhusus Beba, yang bertanggung jawab adalah Dg. Limpo sedangkan di Paotere yang bertanggung jawab adalah Dg. Rangga. Dg. Limpo sendiri merupakan juragan dengan modal dan kapal terbanyak di Sampulungan, hampir semua 
punggawa-sawi sebelum melakukan penangkapan akan mengambil barang (pinjaman) kepada Dg. Limpo.

Jika terjadi kerugian maka terlebih dahulu hasil penjualan ikan atau telur ikan akan digunakan untuk membayar pinjaman modal punggawa-sawi kepada juragan, tetapi tidak ada unsur pemaksaan. Terkadang pula juragan akan mendahulukan membagi hasilnya dengan punggawa-sawi dengan menunda pembayaran pinjaman dari punggawa-sawi. Hal tersebut dikarenakan baik pihak punggawa-sawi ataupun juragan harus sama-sama mendapatkan keuntungan atau harus sama-sama menanggung kerugian.

Bentuk kerja sama yang dianut oleh juragan-punggawa sawi di Desa Sampulungan tersebut telah menjadi sebuah kebiasaan. Di mana mereka tidak lagi mengulang-ulangi akad yang dilakukan. Hal tersebut dikarenakan tidak terjadi perubahan akad dari awal berdirinya kerja sama tersebut hingga saat ini. Sebagaimana pernyataan dari Dg. Limpo

Tidak pernah lagi akad kalau ada yang mau pergi melaut, tidak ada yang berubah selalu seperti itu perjanjiannya dan cara baginya.kalau di ulangi lagi terus saya sudah tidak bias ke mana-mana. Kalau ada yang mau pergi melaut ya pergi saja tinggal ambil barang keperluannya di sini. Saya juga punya anak yang bantu urus di sini. Jadi kalau saya tidak ada, ada anak saya yang catat semua transaksinya

Sistem kemitraan secara turun temurun tersebut telah dilakukan puluhan tahun yang lalu dan tidak mengalami perubahan. Jika ada nelayan baru yang berasal dari luar Sampulungan maka akad akan dijelaskan ulang oleh punggawa kapal (punggawa-sawi) sebagai penanggung jawab kapal dan para nelayan yang di bawahnya. Punggawa (punggawasawi) juga akan bertanggung jawab untuk membagikan hasil dari usaha penangkapan setelah pihak juragan mengambil keuntungan dari hasil penangkapan. Pihak punggawa kapal merupakan penghubung antara juragan dan nelayan (punggawa-sawi), punggawa kapal (punggawa-sawi) akan menyampaikan kebutuhan nelayan (punggawa-sawi) kepada pihak juragan termasuk membagikan hasil tangkapan.

\section{Contoh Bagi Hasil Juragan-Punggawa Sawi}

Juragan mengeluarkan investasi berupa jolloro yang senilai Rp. 150.000.000 dan punggawa-sawi mengeluarkan biaya tetap sekitar Rp. 6.00o.ooo. untuk penangkapan ikan dilakukan selama 15 hari melaut semenjak meninggalkan daratan hingga tiba di daratan kembali. Penangkapan ikan dilakukan oleh 7 orang client. Jika seluruh ikan hasil penangkapan di jual dengan total keuntungan kotor sebesar Rp. 20.000.00o maka perhitungannya adalah sebagai berikut : 


$$
\begin{aligned}
& \text { Perspektif Islam Terhadap Distribusi Kekayaan Dalam Hubungan } \\
& \text { Juragan-Punggawa Sawi Pada Kehidupan Nelayan } \\
& \text { Ardhina Nur Aflaha } \\
& \text { DOI: 10.24252/iqtisaduna.v5i2.10550 } \\
& \text { Pd = TR- TC }
\end{aligned}
$$

Dimana :

$$
\begin{aligned}
& \text { Pd }=\text { Keuntungan (profit) } \\
& \text { TR }=\text { Total penerimaan (Total Revenue) } \\
& \text { TC }=\text { Biaya Produksi }
\end{aligned}
$$

Maka Pd = Rp. 20.000.000 - Rp. 6.000.000 = Rp 14.000.000

$\mathrm{Pd}: 25 \%$ = keuntungan juragan

Rp. $14.000 .000: 25 \%=$ Rp. 3.100 .000

$\mathrm{Pd}-$ keuntungan juragan = keuntungan punggawa-sawi

Rp. 14.000.000- Rp. 3.100.000 = Rp 10.900.000

Keuntungan punggawa-sawi : jumlah punggawa-sawi $=$ keuntungan masing-masing punggawa-sawi

Rp. 18.000.000 : 8 = Rp. 1.362.500

Dari hasil tersebut dapat dilihat biaya pertama yang dikeluarkan oleh juragan dari hasil penangkapan ikan yakni modal punggawa-sawi hal tersebut dikarenakan modal yang dikeluarkan punggawa-sawi merupakan pinjaman dari juragan yang akan dibayar ketika selesai penangkapan atau jika tidak ada hasil maka akan dibayar ketika pihak punggawa-sawi memiliki uang.

Pembagian antara punggawa-sawi juga dimana punggawa-sawi yang beroperasi sebagai nelayan mendapatkan 1 seperti contoh di atas maka client masing-masing mendapatkan Rp. 1.362.500 bagian sedangkan punggawa kapal mendapatkan 2 bagian dari yang didapatkan oleh punggawa-sawi yakni Rp. 2.725.ooo. Pihak juragan akan mendapatkan keuntungan 25\% dari keuntungan bersih yakni Rp 3.100.00o.

Hal diatas sesuai dengan wawancara yang dilakukan kepada Riswan selaku anak dari Dg.Limpo yang bertugas untuk melakukan pencatatan

Di sini sistemnya kami sebagai juragan punya jolloro lalu mereka (nelayan) mengambil barang keperluan dari kami untuk turun menangkap ikan atau telur. Rata-rata semua nelayan ambil barang di sini. Nanti setelah penangkapan dan sudah ada hasil penjualannya baru kami langsung potong harga barang yang mereka ambil. Itupun kalau modal bisa kembali, kalau tidak nanti saja bayarnya kalau mereka melaut lagi dan dapat hasil lebih banyak. Kalau sudah selesai iptotong pinjaman, langsung diambil keuntungan untuk juragannya. Setelah itu uang sisanya diberikan kepada punggaw masing-masing kapal. Nanti punggawa yang bagikan ke nelayannya. Karena di sini cumin bertugas member dan menjual barang, kalau ada hubungan ke nelayan itu tugasnya punggawa. Tetapi kalau nelayan butuh pinjaman untuk hari-harinya biasanya langsung ke sini 


\section{Perspektif Islam Terhadap Distribusi Kekayaan Dalam Hubungan Juragan-Punggawa Sawi Pada Kehidupan Nelayan Ardhina Nur Aflaha \\ DOI: 10.24252/iqtisaduna.v5i2.10550}

\section{Investasi Usaha}

Investasi merupakan penanaman modal dalam suatu usaha kegiatan yang memiliki masa atau jangka waktu yang panjang yang dapat digunakan dalam beberapa kali operasi kegiatan usaha, berbeda dengan biaya yang hanya berlaku untuk satu kali operasi saja. Investasi yang dibutuhkan dalam kerja sama juragan-punggawa sawi dapat dilihat pada tabel berikut

Tabel 2. Investasi

\begin{tabular}{lll}
\hline No. & Jenis Investasi & Nilai (Rp) \\
\hline $\mathbf{1}$ & Kapal & 100.000 .000 \\
\hline $\mathbf{2}$ & Mesin Kapal & 26.000 .000 \\
\hline $\mathbf{3}$ & Generator & 2.300 .000 \\
\hline $\mathbf{4}$ & Basket & 20.000 .000 \\
\hline $\mathbf{5}$ & Lampu & 1.000 .000 \\
\hline $\mathbf{6}$ & Kabel & 700.000 \\
\hline & Total & 150.000 .000
\end{tabular}

Sumber : Data Primer yang telah diolah 2017

Pada tabel tersebut investasi yang dilakukan oleh juragan sejumlah Rp. 150.000.0oo, investasi tersebut menjadi modal yang dikeluarkan oleh juragan dalam melakukan kerja sama kemitraan dengan punggawa-sawi. Modal dari juragan berupa kapal yang telah lengkap seperti dijelaskan sebelumnya kapal inilah yang disebut Jolloro oleh penduduk Sampulungan. Investasi terbesar adalah kapal atau biasa di sebut jollooro. Jolloro tersebut biasanya di buat di Sampulungan dengan mendatangkan pembuat jolloro, tukang tersebut berasal dari Galesong. Biaya jolloro mencakup bahan baku yang digunakan derta gaji dari tukang sendiri. Tiap juragan memiliki jolloro mereka masing-masing, tetapi jumlahnya tidak sama. Contohnya saja Dg. Beta hanya memiliki 2 jolloro sedangkan Dg. Limpo memiliki 5 jolloro. Sedangkan biaya terendah adalah biaya kabel yang digunakan untuk kabel lampu pada jolloro.

\section{Biaya}

Biaya dalam kerja sama yang dilakukan oleh juragan-punggawa sawi adalah biaya yang bersifat tidak tetap. Biaya tidak tetap adalah biaya yang berubah-ubah sesuai dengan kebutuhan punggawa-sawi saat berada di laut.

Biaya yang dibutuhkan penangkap ikan dan penangkap telur ikan jelas berbeda, hal tersebut dikarenakan lama penangkapan berbeda. Penangkapan ikan dilakukan selama 13-15 hari terhitung sejak berangkat hingga kembali ke darat. Penangkapan ikan biasanya dilakukan di perbatasan antara laut Sulawesi dan Kalimantan dan dilakukan sepanjang tahun, maksimal 
dalam sebulan kapal dapat turun 2 kali. Jumlah punggawa-sawi juga berbeda, jumlah punggawa-sawi pada kapal penangkap ikan yakni 7-8 orang. Jumlah biaya tidak tetap yang dikeluarkan punggawa-sawi saat turun melaut salah satunya dapat dilihat melalui tabel berikut:

Tabel 3. Biaya Tidak Tetap Penangkapan Ikan

\begin{tabular}{lll}
\hline NO & Jenis Pengeluaran & Nilai (Rp) \\
\hline $\mathbf{1}$ & Solar & 2.073 .800 \\
\hline $\mathbf{2}$ & Bensin & 217.500 \\
\hline $\mathbf{4}$ & Gula & 221.000 \\
\hline $\mathbf{5}$ & Minyak goring & 60.000 \\
\hline $\mathbf{6}$ & Oli & 145.000 \\
\hline $\mathbf{7}$ & Ikan & 1.350 .000 \\
\hline $\mathbf{8}$ & Rokok & 1.020 .000 \\
\hline $\mathbf{9}$ & Kopi, kuku bima, susu & 347.000 \\
\hline $\mathbf{1 0}$ & Es balok & 800.000 \\
\hline Jumlah & 6.234 .300
\end{tabular}

Sumber : Data Primer yang telah diolah 2017

Tabel tersebut menyebutkan beberapa kebutuhan punggawa-sawi saat berada di laut, perlu diketahui bahwa pengeluaran tersebut bergantung pada punggawa-sawi, jadi biaya pada tabel tersebut dapat berubah-ubah sesuai kondisi dan kebutuhan dari punggawa-sawi. Table di atas hanya menjelaskan biaya tidak tetap dari penangkapan ikan sedangkan biaya tidak tetap penangkapan telur ikan lebih besar.

Tabel 4. Biaya tidak tetap penangkapan telur ikan

\begin{tabular}{lll}
\hline NO & Jenis Pengeluaran & Nilai (Rp) \\
\hline $\mathbf{1}$ & Solar & 16.590 .400 \\
\hline $\mathbf{2}$ & Bensin & 1.736 .000 \\
\hline $\mathbf{4}$ & Gula & 1.768 .000 \\
\hline $\mathbf{5}$ & Minyak goring & 480.000 \\
\hline $\mathbf{6}$ & Oli & 1.160 .000 \\
\hline $\mathbf{7}$ & Es balok & 6.400 .000 \\
\hline $\mathbf{8}$ & Rokok & 8.160 .000 \\
\hline $\mathbf{9}$ & Kopi, kuku bima, susu & 2.776 .000 \\
\hline $\mathbf{1 0}$ & Lain-lain & 20.125 .600 \\
\hline Jumlah & 70.000 .000
\end{tabular}

Sumber : Data Primer yang telah diolah 2017 


\section{Perspektif Islam Terhadap Distribusi Kekayaan Dalam Hubungan Juragan-Punggawa Sawi Pada Kehidupan Nelayan Ardhina Nur Aflaha \\ DOI: 10.24252/iqtisaduna.v5i2.10550}

Biaya terbesar yang dikeluarkan nelayan yakni biaya solar sebesar Rp. 2.073.800 hal tersebut dikarena lamanya nelayan berada di laut. Selama 13-15 hari di laut nelayan membawa persediaan solar. Sedangkan biaya terendah yakni minyak goreng sebesar Rp 60.00o. Banyaknya kebutuhan nelayan mencakup biaya kebutuhan pokok berupa makanan nelayan selama di laut.

Berdasarkan tabel di atas dapat dilihat biaya terbesar juga jatuh pada biaya solar, biaya lain-lain termasuk biaya pinjaman nelayan sebelum melaut, serta kebutuhan lainnya. Biaya terendah jatuh pada kebutuhan minak goring. Untuk penangkap telur ikan, punggawa-sawi tidak selamanya berada di laut. Punggawa-sawi kadang-kadang naik ke daratan untuk menelpon, mencari kebutuhan yang lainnya ataupun untuk bertemu dengan juragan untuk menjual hasil penangkapan.

Biaya tidak tetap akan ditanggung oleh punggawa-sawi sendiri. Tetapi biaya tidak tetap yang dikeluarkan oleh punggawa-sawi tersebut merupakan pinjaman yang berasal dari juragan. Pinjaman tersebut akan dibayarkan ketika punggawa-sawi selesai melakukan penangkapan yang akan dipotong langsung dari hasil melaut. Sebagaimana yang dikatakan oleh Dg. Tompo

Ini modal kami ambil dari Dg. Limpo. Nanti kalau sudah melaut kami bayar. Tetapi kalau tidak ada hasil dianggap hpinjaman dulu nanti baru kami bayar kalau sudah ada uang. Atau biasa juga nanti dipotong kalau kami turun lagi tangkap ikan dan dapat hasilnya.

Seperti yang dapat dilihat di Sampulungan. Sebelum melakukan penangkapan pihak punggawa-sawi akan mengambil beberapa barang keperluan yang dibutuhkan saat penangkapan di warung milik juragan, juragan akan menghitung jumlah yang di ambil dan dicatat sebagai pinjaman, biasanya berkisar antara Rp 6-7 juta untuk penangkapan ikan dan Rp 70-100 juta untuk penangkapan telur. Selanjutnya apabila hasil penangkapan ikan menghasilkan Rp. 30.0oo.ooo, maka sebelum melakukan pembagian, pihak juragan akan langsung memotong sesuai dengan pinjaman dari punggawa-sawi.

Apabila punggawa-sawi tidak mendapatkan hasil dari penangkapan atau kurang untuk membayar pinjaman yang telah diambil, maka pinjaman tersebut akan dibayar setelah punggawa-sawi memiliki uang dari hasil penangkapannya. Pinjaman tersebut tidak memiliki jangka waktu dan dapat bertambah sesuai dengan kebutuhan dari punggawa-sawi.

\section{Jangka Waktu Kerja Sama}

Jangka waktu kerja sama antara juragan-punggawa sawi terbagi atas dua, yakni kerja sama untuk penangkapan ikan dan untuk penangkapan telur ikan. Kerja sama yang dijalani 
untuk penangkapan ikan berlangsung selama 13-15 hari, sedangkan untuk penangkapan telur ikan bisa berlangsung selama 4-5 bulan lamanya dan dilakukan sepanjang tahun.

Di desa Sampulungan sendiri tidak ada larangangn khusus untuk turun melaut, para punggawa-sawi sudah terbiasa dengan segala kondisi laut, baik ombak tinggi ataupun angin kencang. Jamaluddin mengatakan

Angin dan ombak besar biasanya hanya terjadi di sebagian tiitk. Bisa jadi disini keras, di batas Kalimantan itu tidak. Bisa juga di sini tenang di batas Kalimantan justru keras. Ya kita semua turun saja melaut terus, kalau tidak begitu apa yang mau kita makan?

Pernyataan tersebut menggambarkan ketergantungan nelayan untuk turun melaut serta tidak adanya batasan waktu untuk turun melaut. Melakukan penangkapan sudah menjadi bagian dari hidup mereka, tanpa melaut mereka tidak memiliki pekerjaan lain untuk memenuhi kebutuhan mereka. Namun pada bulan april-mei pendapatan juragan-punggawa sawi berkurang dikarenakan jumlah ikan hasil tangkapan sedikit hal ini dipengaruhi oleh musim karena antara april hingga mei terjadi peralihan musim.

Dari hasil penangkapan ikan 25\% untuk juragan 75\% untuk punggawa sawi. Di mana untuk punggawa sawi akan dibagi sesuai dengan jumlah nelayan dan punggawa yang ikut di dalam proses penangkapan dan punggawa berhak mendapatkan jatah 2 kali lipat dari jatah satu orang nelayan. Sedangkan untuk penangkapaan telur ikan dari hasil penangkapan 25\% untuk juragan, 70\% untuk punggawa sawi dan 5\% untuk jasa menjual telur ikan. Di mana untuk punggawa sawi akan dibagi sesuai dengam jumlah nelayan dan punggawa yang ikut di dalam proses penangkapan dan punggawa berhak mendapatkan jatah 2 kali lipat dari jatah satu orang nelayan.

Dari pemaparan kerja sama di atas maka dapat kita peroleh bahwa syarat yangberkaitan dengan syarik yaitu pihak juragan-punggawa sawi mengatur jumlah modal yang akan diberikan dalam usaha penangkapan dan saling membagi pekerjaan sesuai dengan keahlian masing-masing. Juragan yang bertugas menjual hasil penangkapan dan punggawa sawi melakukan penangkapan. Dapat ketahui juga keuntungan yang diperoleh harus ditentukan berdasarkan jumlah modal yang disertakan (proporsional) tetapi pendapat Abu Hanifah mengatakan boleh membagi hasil tidak sesuai dengan modal yang dimasukkan. Pendapat dari Abu Hanifah ini sejalan dengan yang terjadi di Desa Sampulungan. Perbandingan kasus Sampulungan dengan teori fiqih muamalah dapat dilihat dalam tabel berikut 


\section{Perspektif Islam Terhadap Distribusi Kekayaan Dalam Hubungan Juragan-Punggawa Sawi Pada Kehidupan Nelayan Ardhina Nur Aflaha \\ DOI: 10.24252/iqtisaduna.v5i2.10550}

Tabel 5. Perbandingan Empiris dan Teoritias

\begin{tabular}{|c|c|c|c|}
\hline No & Indikator & $\begin{array}{l}\text { Bagi Hasil Desa } \\
\text { Sampulungan }\end{array}$ & Fiqh Muamalah \\
\hline 1 & Modal dan tenaga & $\begin{array}{l}\text { Modal ditanggung kedua } \\
\text { belah pihak. Juragan } \\
\text { mengerluarkan modal berupa } \\
\text { jolloro beserta at yang } \\
\text { dibutuhkan } \\
\text { punggawa-sawi } \\
\text { mengeluarkan modal berupa } \\
\text { barang-barang rangan } \\
\text { dibutuhkan selama melaut. } \\
\text { Tenaga yang dikeluarkan } \\
\text { juragan yakni juragan } \\
\text { bertugas melakukan } \\
\text { penjualan ikan dan } \\
\text { mengantarkan kebutuhan } \\
\text { yang diperlukan punggawa- } \\
\text { sawi selama melaut. } \\
\text { Punggawa-sawi bertuga } \\
\text { melakukan penangkapan } \\
\text { ikan atautelur ikan. }\end{array}$ & $\begin{array}{l}\text { Apabila masing-masing } \\
\text { syarik telah menanggung } \\
\text { modal dan tenaga atau } \\
\text { pembagian pekerjaan maka } \\
\text { sah dikatakan sebagai } \\
\text { syirkah inan }\end{array}$ \\
\hline 2 & Akad & $\begin{array}{l}\text { Tidak dilakukan lagi karena } \\
\text { kerja sama bagi hasil ini telah } \\
\text { terjadi secara berulang-ulang } \\
\text { dan tidak ada perbaharuan } \\
\text { akad }\end{array}$ & $\begin{array}{l}\text { Dalam akad syirkah inan } \\
\text { wajib menetukan modal } \\
\text { usaha, kerja dan nisbah } \\
\text { yang akan diperoleh }\end{array}$ \\
\hline 3 & $\begin{array}{l}\text { Jangka waktu kerja } \\
\text { sama }\end{array}$ & $\begin{array}{l}\text { Di mulai sejak punggawa- } \\
\text { sawi berangkat mealut hingga } \\
\text { kembali }\end{array}$ & $\begin{array}{l}\text { Dilakukan penetuan jangka } \\
\text { waktu saat akad }\end{array}$ \\
\hline 4 & Resiko & $\begin{array}{ll}\text { Resiko ditanggung } & \text { kedua } \\
\text { belah pihak baik } & \text { pihak } \\
\text { juragan ataupun } & \text { pihak } \\
\text { punggawa-sawi } & \end{array}$ & $\begin{array}{lr}\text { Secara umum syirkah } \\
\text { meberlakukan resiko atau } \\
\text { kerugian } & \text { ditanggung } \\
\text { bersama } & \\
\end{array}$ \\
\hline 5 & $\begin{array}{l}\text { Waktu penentuan } \\
\text { bagi hasil }\end{array}$ & $\begin{array}{l}\text { Tidak diulang lagi karena } \\
\text { pola bagi hasil tetap sama }\end{array}$ & Dilakukan saat akad \\
\hline 6 & $\begin{array}{l}\text { Besar nisbah bagi } \\
\text { hasil }\end{array}$ & $\begin{array}{l}25 \% \text { diberikan kepada pihak } \\
\text { punggawa-sawi sedangkan } \\
\text { sisanya akan dibagi 2:1 } \\
\text { kepada punggawa-sawi di } \\
\text { mana punggawa-sawi yang } \\
\text { bertugas sebagai punggawa } \\
\text { kapal akan mendapatkan } 2 \\
\text { jatah dari sawi }\end{array}$ & $\begin{array}{l}\text { Besarnya nisbah bagi hasil } \\
\text { yang diterima boleh berisfat } \\
\text { proporsional juga } \\
\text { diperbolehkan sesuai } \\
\text { kesepakatan saja. } \\
\text { Sebagaimana pendapat Abu } \\
\text { Haniah yang } \\
\text { memperbolehkan bagi hasil } \\
\text { yang tidak proporsional } \\
\text { dalam akan syirkah inan }\end{array}$ \\
\hline 7 & $\begin{array}{l}\text { Berakhirnya kerja } \\
\text { sama }\end{array}$ & $\begin{array}{l}\text { Kerja sama berakhir setelah } \\
\text { pihak juragan-punggawa } \\
\text { sawi telah mendapatkan } \\
\text { keuntungan dari hasil } \\
\text { penangkapan ikan }\end{array}$ & $\begin{array}{l}\text { Setelah berakirnya kerja } \\
\text { sama anatar syarik yang } \\
\text { ditentukan saat akad atau } \\
\text { terjadi kerusakan modal } \\
\text { usaha }\end{array}$ \\
\hline
\end{tabular}




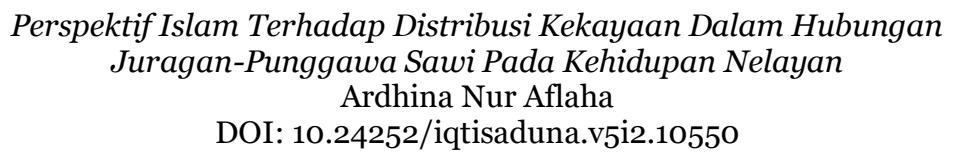

\section{KESIMPULAN}

Konsep distribusi harta dalam hubungan juragan-punggawa sawi terbagi atas dua yakni, pertama dari hasil penangkapan ikan 25\% untuk juragan $75 \%$ untuk punggawa-sawi. Kedua, dari hasil penangkapan telur ikan 25\% untuk juragan 70\% dan 5\% untuk perantara penjual hasil tangkapan.

Dari hasil yang didapatkan distribusi kekayaan yang terjadi pada hubungan yang sesuai dengan prinsip distribusi kekayaan. Distribusi kekayaan yang terjalin antara juraganpunggawa sawi merupakan distribusi kekayaan yang bersifat produktif dan bentuk kerja sama tersebut dalam ekonomi Islam merupakan bentuk kerja sama syirkah .

Kerja sama tersebut dapat terjalin dikarenakan adanya unsur kearifan lokal yang terjalin antara juragan-punggawa sawi dan tidak terlepas dari rasa kekeluargaan. Hal tersebut sangat membantu para nelayan yang tidak memiliki modal untuk tetap mampu berlayar secara individu.

\section{DAFTAR PUSTAKA}

Azwar, Saifuddin, Metode Penelitian, (Cet IV; Yogyakarta; Pustaka Pelajar, 2004)

H.Idri, Hadis Ekonomi: Ekonomi dalam Perspektif Hadis Nabi (Jakarta : Prenadamedia Group. 2015)

Ha>run, Abd. Sala>m, Al-Mu’jam al-Wasit. Juz 1 (Taheran : Al-Maktabah al-Ilmiyyah.tt)

Hanafia, Bachtiar, "Konsep Keuntungan Syirkah al-Inan dari Perspektif Ekonomi Islam”, Disertasi (Kuala Lumpur: Akademi Pengajian Islam Universitas Malaya, 2014)

Haritsi, Jaribah bin Ahmad, Fikih Ekonomi Umar bin Al-Khattab , diterjemahkan ; Asmuni Solihan Zamakhsyari(Jakarta : Khalifah. 2006)

Hasanuddin, Maulana, Perkembangan Akad Musyarakah ( Jakarta : Kencana Prenada Media Group.2012)

http://famifo8. student. ipb. ac. id/2010/06/20/masyarakat-pesisir// (diakses pada tanggal 21 juli 2015)

Qasi >mi, Muhammad Jamal Al Din- >, Tafsir al-Qasi $>$ mi $>$ Jilid 8 (Beirut : Da $>$ r al-Kutub al 'Ilmiyyah.tt)

Rasjid, Sulaiman, Fiqh Islam (Bandung: Sinar Baru Algesindo, 2011)

Razali, Ivan, Strategi Pembangunan Masyarakat Pesisir dan Laut . Jurnal Ilmiah, no. 2 (2004)

Satria, Arif,Pengantar Sosiologi Masyarakat Pesisir (Jakarta : Buku Obor. 2014)

Sayyid Quthb ,Al-'Adalah al-Ijtima’iyyah fil Islam. Alih bahasa Afif Mohammad, (Bandung: Pustaka, 1984)

Sudarsono, Heri, Konsep Ekonomi Islam: Suatu Pengantar (Yogyakarta: Ekonosia UII,2004) 